Aleksandra Snarska

Szkoła Glówna Handlowa

\title{
Kapital klienta a wartość rynkowa na przykładzie bankowości detalicznej
}

\section{CUSTOMER EQUITY AND MARKET VALUE IN RETAIL BANKING}

\begin{abstract}
Niniejszy artykut koncentruje się na badaniu zależności między wartościq życiowa klienta a wartościq rynkowa banków na rynku polskim. Wielu autorów (P. Seybold, S. Gupta, D. Lehmann, R. Boulton, B. Liebert, S. Samek, R. Heiebeler, T. Kelly, Ch. Ketteman, P. Doyle) wykazywato pozytywnq zależność miedzy wartościa przyszłych przepływów pienięznych od bazy klientów firmy a prognozowanq wycenq rynkowa firmy przez inwestorów. Innym zastosowaniem wartości życiowej klienta jest zarzqdzanie kapitatem klienta poprzez rozwijanie klientów, ochrona relacji z nimi, zacieśnianie relacji czy zwiększanie ich wartości. Głównym zatożeniem artykułu jest przybliżenie metody CLV oraz zbadanie rozlicznych korelacji tego wskaźnika z wynikami finansowymi banków gietdowych. Artykut koncentruje się także na metodologiach i trudnościach wyliczania $C L V$. W tym przypadku zbadane zostana dwie metody liczenia CLV-jedna oparta na zysku z działalności podstawowej, a druga hipotetycznie bardziej dokładna na zysku brutto w segmencie operacyjnym detal. W zwiqzku z przyjętym podejściem ukazana zostanie charakterystyka tak rozumianego kapitału klienta na polskim rynku banków giełdowych wyliczana osobno dla CLV na zysku z działalności podstawowej oraz na zysku brutto. Wiele badań wykazywato pozytywna korelacje między wartościa szacunkowych przyszlych przeplywów pieniężnych bazy klienckiej banku a wartościa rynkowa firmy. Finalnie zweryfikowana zostanie hipoteza o wysokiej korelacji między wartościq życiowa bazy klientów banku a jego wartościa rynkowq banków.
\end{abstract}

Słowa kluczowe: wartość życiowa klienta, wartość rynkowa firmy, bankowość detaliczna

\section{Wstęp}

Współczesne teorie zarządzania coraz częściej kładą nacisk na kluczową rolę klienta, kapitału klienta jako podstawowego źródła wartości przedsiębiorstwa. ${ }^{1}$ Teorie wartości przedsiębiorstwa oraz kapitału klienta uznają klientów za podstawowe źródło obecnych i przyszłych przepływów pieniężnych firmy ${ }^{2}$. Zgodnie z Rysunkiem 1 nacisk kładziony na kapitał klienta wynika $\mathrm{w}$ dużej mierze $\mathrm{z}$ rosnącej jego roli $\mathrm{w}$ łańcuchu wartości $\mathrm{w}$ gospodarce internetowej, w warunkach globalizujących się rynków, wzrostu wydajności oraz migracji zasobów. B. Dobiegała Korona wymienia autorów dążących do utrwalenia tezy o konieczności szacowania wartości firm na podstawie prognozowanych przyszłych

\footnotetext{
${ }^{1}$ B. Dobiegała - Korona, Klient kapitałem przedsiębiorstwa, w: red. B. Dobiegała - Korona, A. Herman, Współczesne źródła wartości przedsiębiorstw, Difin, Warszawa, 2006, s. 85.

${ }^{2}$ J. Villanueva, D.M. Hanssens, Customer Equity: Measurement, Management and Research Opportunities, Foundations and Trends in Marketing, Vol. 1, No. 1 (2007), s. 1-95.
} 
przepływów pieniężnych od klientów, takich jak P. Seybold, S. Gupta, D. Lehmann, R. Boulton, B. Liebert, S. Samek, R. Heiebeler, T. Kelly, Ch. Ketteman oraz P. Doyle.

Rysunek 1. Wartość klienta a wartość przedsiębiorstwa

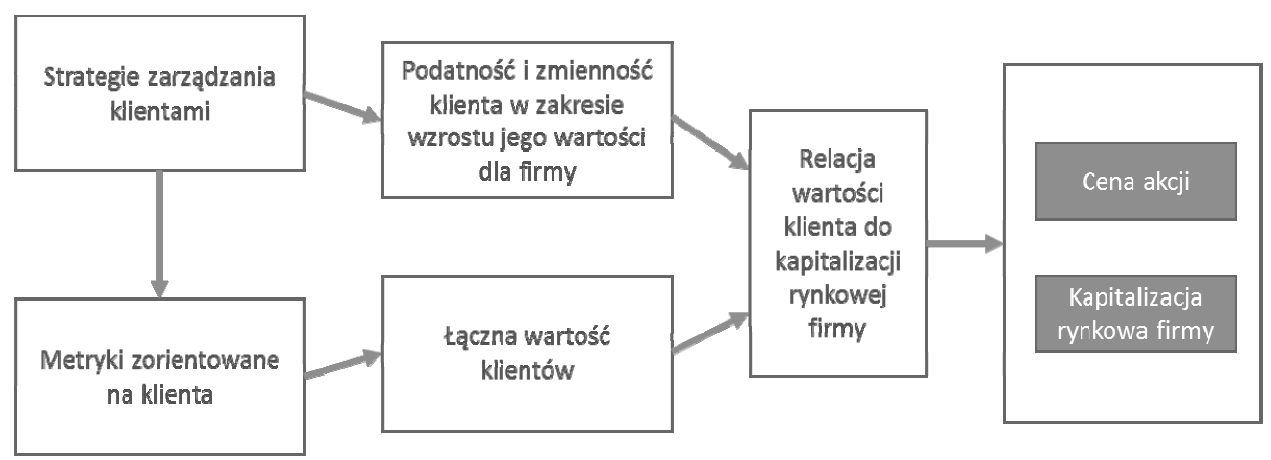

Źródło: B. Dobiegała-Korona, Kierunki i wyzwania...

B. Dobiegała-Korona wskazuje, iż warunkiem koniecznym, w obliczu badań wskazujących na wysoką zależność między kapitałem klienta a wyceną rynkową firmy (Rysunek 1), zarządzania wartością rynkową firmy jest wdrażanie zarządzania o charakterze marketingowym lub wręcz nadanie marketingowi nowej strategicznej, integrującej roli w przedsiębiorstwie ${ }^{3}$. G. S. Day i Ch. Moorman piszą także o tym jak budować kapitał klienta $\mathrm{w}$ oparciu o $\mathrm{CLV}^{4}$. Wskazują na działania jakie bank zarządzający bazą klientów i ich segmentacją powinien podejmować zarówno w celu podnoszenia ich wartości, jak i celem wzrostu ,podatności i zmienności klienta w zakresie wzrostu jego wartości dla firmy" (Rysunek 2).

\footnotetext{
${ }^{3}$ B. Dobiegała-Korona, Kierunki i wyzwania rozwoju zarządzania wartością klientów, w: red. B. Dobiegała Korona, Budowa wartości klienta - teoria i praktyka, Difin, Warszawa, 2015, s. 22.

${ }^{4}$ G. S. Day, Ch. Moorman, Strategy from the Outside In. Profiting from the Customer Value, McGraw Hill, 2010, s. 145
} 
Rysunek 2. Wytyczne zarządzania aktywami klienta

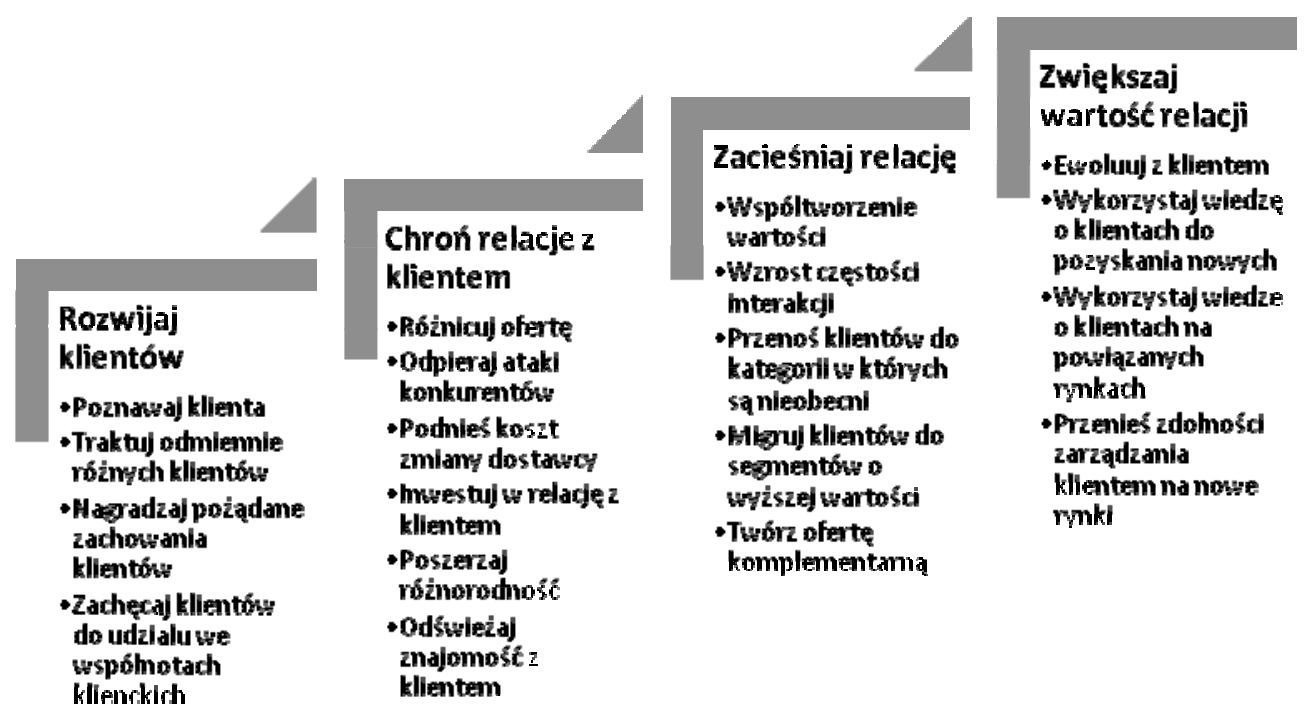

Źródło: G.S. Day, Ch. Moorman, Strategy from Outside In..

Niniejszy artykuł koncentruje się na wycenie banków detalicznych w Polsce w latach 2011-2013 metodą CLV oraz podejmuje próbę ustalenia wpływu obliczonego w ten sposób kapitału klienta na wycenę rynkową banków. Przy czym artykuł ten jest częścią badania koncentrującego się na wartości dla klientów w bankowości detalicznej w Polsce, pomija bowiem więc analizę wpływu pozostałych segmentów operacyjnych bankowości poza segmentem detalicznym.

Wybór bankowości detalicznej motywować można przede wszystkim dostępnością danych, ale także większą łatwością szacowania i pozyskiwania danych dotyczących retencji, wydatków marketingowych etc. P. Fader proponuje charakterystykę firm, które powinny koncentrować się na klientach i cenić kapitał klienta ponad kapitał marki jako firmy usługowe, kontraktowe, czyli zawierające z klientem umowę na dłuższy okres czy firmy, których ofertę można kastomizować. ${ }^{5}$ Wskazuje to na bankowość jako na sektor, w którym łatwe i zasadne byłoby kierowanie się koncepcją zarządzania kapitałem klienta i zarządzania klientami jako portfelem inwestycji.

Autorka pracy koncentruje się na poziomie bardziej zagregowanym i przybliża charakterystykę CLV w polskich bankach, głównie giełdowych, a następnie koncentruje się na kluczowym badaniu wpływu kapitału klienta na wartość rynkową banków, jedynie jak wyżej podkreślono w segmencie detalicznym. Ze względu na dobór metody badań autorka wskazuje na jej ograniczenia oraz zastosowane szacunki dla wartości wykorzystanych w modelu.

${ }^{5}$ P. Fader, Customer Centricity, Focus on the Right Customers for Strategic Advantage, Wharton Executive Essentials, Philadelphia, 2012, s. 66. 


\section{Metodologia badań i przyjęte założenia}

Kapitał klienta definiuje się najczęściej jako sumę wszystkich wartości życiowych klientów danej firmy ${ }^{6}$. Wskazuje się na konieczność angażowania zasobów firmy celem maksymalizacji kapitału klienta oraz przede wszystkim kwantyfikacji jego wartości życiowej. CLV (życiowa wartość klienta) mierzy zdyskontowaną wartość przepływów pieniężnych istniejących i przyszłych klientów, których wartość bieżąca ma według autorów przekładać się na prognozowaną wartość firmy. ${ }^{7}$ Obok kategorii wartości życiowej klienta CLV w artykule posłużymy się także kategorią kapitału klienta. Przez kapitał klienta rozumiemy sumę wszystkich wartości życiowych klientów banku.

J. Villanueva i D. M. Hanssens wymieniają rozliczne źródła liczenia kapitału klienta: wewnętrzne bazy danych (modele deterministyczne, migracji klientów etc.), metody kwestionariuszowe, sprawozdania firm, dane panelowe oraz ocena menedżerska ${ }^{8}$. Modele zarządcze są według nich najczęściej stosowane w praktyce, częściowo ze względu na to, iż pozostałe metody są nowe a także wymagają bardzo złożonych modeli ekonometrycznych i dużych baz danych.

W badaniu wykorzystana zostanie metoda CLV (wartość życiowa klientów) wyliczona zgodnie z wytycznymi S. Gupty i D. Lehmanna z 2004 roku, jeden z tak zwanych „modeli zarządczych”. J. Villanueva i D. M. Hanssens kładą nacisk na jej ograniczenia. Z braku danych nie uwzględnia się w nim wielu czynników, przykładowo przyszłych kohort klientów, nie wyznacza się jednocześnie optymalnej retencji i pozyskania, które przecinają się w punkcie $(0 ; 0)$. Metoda ta sprawdza się więc tylko na poziomie zagregowanym firmy. W rzeczywistości występuje konieczność ustalania CLV dla poszczególnych segmentów a nie dla całej bazy aby znać najbardziej zyskowne segmenty. Nie bierze ona także pod uwagę faktu, iż utrata klienta oznacza utratę jego CLV, a także spadek poleceń, utratę funduszy na pozyskanie klienta oraz możliwy spadek jego wpływu na inne segmenty (np. adopcja przez klientów imitujących, efekty sieci). Nie uwzględnia ona też wpływu konkurencji np. obniżki cen oraz zróżnicowanych źródeł ryzyka.

Mając świadomość licznych ograniczeń oraz przyjętych założeń w niniejszej pracy wykorzystany zostanie model uproszczony „menedżerski” Gupty, Lehmana z 2004 roku, według którego:

$$
\mathrm{CLV}=\underset{\text { Zlienta }}{\text { Zysk } /} * \frac{\mathrm{R}}{1+\mathrm{D}-\mathrm{R}^{*}(1+\mathrm{G})}-\mathrm{A}
$$

Gdzie:

$$
\text { - } \mathrm{R}-\text { retencja }
$$

\footnotetext{
${ }^{6}$ P. Fader, Customer Centricity, Focus on the Right Customers for Strategic Advantage, Wharton Executive Essentials, Philadelphia, 2012, s. 62

${ }^{7}$ S. Gupta, D.R. Lehman, J.A. Stuart, Valuing Customers, Journal of Marketing Research, XLI, 2004, s. 7-18

${ }^{8}$ J. Villanueva, D.M. Hanssens, Customer Equity: Measurement, Management and Research Opportunities, Foundations and Trends in Marketing, Vol. 1, No. 1 (2007), s. 1-95
} 
- $\quad$ D - stopa dyskontowa $(=$ WACC $)$

- $\quad$ G - stopa wzrostu (zał. $=5 \%$ )

- A - koszt pozyskania klienta (uwzględniony przy liczeniu CLV na zysku z działalności podstawowej)

W badanym modelu w celu obliczenia zysku wykorzystano dane ze sprawozdań finansowych banków dla segmentu detalicznego oraz dla banków nie giełdowych, takich jak Bank Pocztowy, Credit Agricole oraz Eurobank, gdzie działalność niedetaliczna jest marginalna, więc uwzględniano zyski dla banku jako całości. Założeniem przyjętym dla prognozowanych przyszłych przepływów pieniężnych od klientów, jak i pozostałych zmiennych było to, iż wykazują one cechy stałości w czasie.

Już kategoria zysku przysporzyła trudności, jako że tradycyjnie CLV liczone jest na podstawie zysku ze sprzedaży i pomniejsza się go o wydatki na marketing. Logicznym powinno być więc przyjęcie zysku na działalności podstawowej i pomniejszenie CLV o wydatki na marketing (dane Instytutu Monitorowania Mediów dotyczące średnio rocznych wydatków na reklamę TV). Powstaje jednak pytanie o to, dlaczego model miałby pomijać odpisy netto na utratę wartości udzielonych kredytów oraz koszty działania, których znaczna część to koszty osobowe związane z obsługą klienta, co prowadziłoby do wniosku, iż wykorzystanie zysku brutto byłoby zasadne. Obie wartości mają swoje pozytywne jaki i negatywne cechy (por. Tabela 1), w efekcie jednak CLV liczono na dwa sposoby: osobno na zysku z działalności podstawowej (wynik z prowizji i odsetek), pomniejszane o wydatki na marketing na klienta oraz na zysku brutto.

Tabela 1. Metody liczenia CLV

\begin{tabular}{|c|c|c|}
\hline & $\begin{array}{l}\text { CLV na zysku z dzialalności } \\
\text { podstawowej }\end{array}$ & CLV na zysku brutto \\
\hline $\mathbf{Z a}$ & $\begin{array}{l}\text { - Koncentruje się na kosztach i } \\
\text { przychodach bezpośrednio od } \\
\text { klienta } \\
\text { - Ścisła alokacja kosztów przez } \\
\text { banki daje lepszą porównywalność }\end{array}$ & $\begin{array}{l}\text { - Obejmuje wszystkie koszty } \\
\text { związane z obsługą segmentu } \\
\text { - Kapitał klienta powinien } \\
\text { wykazywać wyższą zbieżność z } \\
\text { MV na poziomie CLV na zysku } \\
\text { brutto } \\
\text { - Wykazuje więcej korelacji }\end{array}$ \\
\hline Przeciw & $\begin{array}{l}\text { - Duże zróżnicowanie wydatków } \\
\text { marketingowych w czasie } \\
\text { (dostępność danych za } 2 \text { lata) } \\
\text { - Brakuje odpisów z tytułu utraty } \\
\text { wartości i kosztów działania }\end{array}$ & $\begin{array}{l}\text { - Różna alokacja kosztów do } \\
\text { segmentów p. banki } \\
\text { - Dość częste zjawisko osiągania } \\
\text { straty na segmencie detalicznym } \\
\text { - Mniejsze wartości o wyższym } \\
\text { stopniu zróżnicowania }\end{array}$ \\
\hline
\end{tabular}

Źródło: opracowanie własne

Problemów przysporzyły także wyliczenia dotyczące liczby klientów, co wynikało w dużej mierze $\mathrm{z}$ faktu, iż banki różne sposoby szacują ich liczbę różniąc się w podejściu do definicji klienta aktywnego. Wykorzystałam, w związku z tym, dane na temat liczby klientów banków, które ją raportowały oraz szacunek na podstawie liczby ROR'ów dla pozostałych. Banki raportują co roku liczbę ROR'ów serwisowi PRNews.pl i z danej tej 
często korzystają znane mi firmy konsultingowe. Objęte badaniem banki, które raportowały liczbę klientów miały od 1,2 do 1,9 klienta na ROR, przy średniej 1,5 klienta na ROR, co skłoniło mnie do przyznania 1,5 klienta na ROR pozostałym bankom.

Kolejne szacunki dotyczyły mnożnika CLV obrazującego jak wiele razy bank jest w stanie pomnożyć zyski od klienta. Jeśli chodzi o prognozowany wzrost zysków postanowiłam przyjąć sztywne założenie, iż będzie on wynosić 5\% rocznie dla wszystkich banków objętych badaniem, stopę dyskontową reprezentować będzie średnio ważony koszt kapitału WACC, który otrzymałam dla banków giełdowych z serwisu Stock Watch (bankom nie giełdowym przyznałam uśrednioną wartość WACC dla banków giełdowych).

Najtrudniejsze założenia dotyczyły kluczowego dla CLV czynnika jakim jest retencja. Pierwszym poczynionym założeniem, było to że utracony klient powraca na takich samych zasadach jak każdy nowo pozyskany klient. Jeśli chodzi o wartości to $\mathrm{z}$ braku danych posłużyłam się raportem Bain \& Co, który ujawnił jedynie iż w polskim sektorze bankowości detalicznej churn wynosi średnio 4,7\%, przy czym maksimum to $5,0 \%$, a minimum to $3,1 \%$. Postanowiłam proporcje uzależnić od składowej NPS (TNS Polska), jaką jest udział Krytyków, czyli klientów którzy poleciliby bank na mniej niż 7 w skali od 1 do 10 (bardzo dobry wynik w tym względzie Raiffeisena, który jest bankiem nie giełdowym i nie był objęty częścią analiz w badanej grupie churn kształtuje się na poziomie od $3,7 \%$ do $5,0 \%$ ).

W równaniu CLV zmiennymi będą więc: zysk na klienta, retencja (na wykresie churn) oraz WACC wyliczony przez analityka Stock Watch. Rysunek 3 prezentuje zmienne dla zysku na działalności podstawowej, który jak już wskazano w Tabeli 1 jest ściślej dookreślony poprzez brak dowolności w alokacji kosztów czy przychodów.

Rysunek 3. CLV Składowe: WACC, churn, zysk z dz podstawowej na klienta

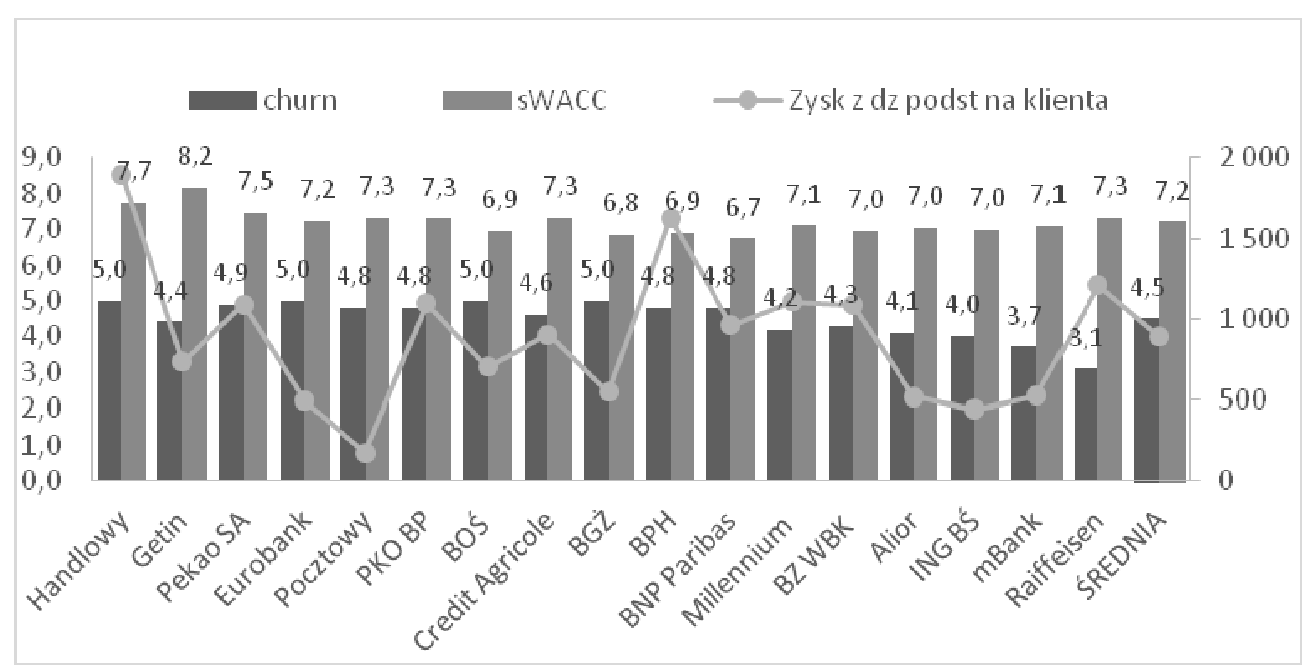

Źródło: opracowanie własne 


\section{Charakterystyka CLV na polskim rynku bankowości detalicznej}

Zanim przejdziemy do kluczowych wyników korelujących wartość rynkową banków z kapitałem klienta liczonym metodą CLV, konieczne będzie zagłębienie się w sam wskaźnik i jego zmiany, co także dostarczy ciekawych i wymagających pogłębionych badań wyników i spostrzeżeń. W niniejszej pracy jak już wspomniano, CLV policzono metodą menedżerską i kształtuje się w segmencie detalicznym dla polskich banków jak w Tabeli 2:

a) pierwszy wariant kalkuluje zysk jako wynik na działalności podstawowej i pomniejsza wynik o wydatki na marketing,

b) drugi natomiast obejmuje także koszty działania oraz odpisy i opiera się na zysku brutto $\mathrm{z}$ detalu.

Pierwszą kwestią którą warto poruszyć to zróżnicowanie relacji CLV na zysku brutto do CLV liczonego metodą tradycyjną (szczegółowe wyniki prezentuje Tabela 2). Relacja CLV oparta na zysku brutto do CLV na zysku na działalności podstawowej dla banków dużych o znacznych sieciach sprzedaży ING, WBK, Citi Handlowy oscyluje wokół $30 \%$, dla PKO BP, Pekao i Millennium nawet $40 \%$, co świadczy o tym, że wdrażają one programy zarządzania kosztami w sieciach sprzedaży. Bezoddziałowy mBank natomiast osiaga wynik zbliżony do $50 \%$. Alior ponoszący wciąż wysokie koszty wzrostu wypada słabiej niż reszta, osiagając wynik w granicach $15 \%$. Część banków poniosła stratę na detalu, co uniemożliwiło dokonywanie dalszych porównań. Należy mieć na uwadze, iż banki rozwijające się, takie jak Pocztowy czy Alior ponoszą nadal wysokie koszty wzrostu, co sprawia że lepiej porównywać je z resztą w wariancie 1 , czyli CLV na wyniku z działalności podstawowej.

Tabela 2. Wyniki wyliczeń CLV dla banków detalicznych dla zysku z działalności podstawowej i zysku brutto

\begin{tabular}{|c|c|c|c|c|c|c|c|c|c|c|}
\hline & \multicolumn{5}{|c|}{ CLV na wyniku z dzialalności podstawowej } & \multicolumn{5}{|c|}{ CLV na wyniku brutto } \\
\hline & CLV & CLV & CLV & $\begin{array}{c}\text { średni } \\
\text { a }\end{array}$ & $\Delta \mathbf{C L V}$ & CLV & CLV & CLV & $\begin{array}{c}\text { Średni } \\
\text { a }\end{array}$ & $\triangle \mathbf{C L V}$ \\
\hline & 2011 & 2012 & 2013 & $\begin{array}{c}2011- \\
13\end{array}$ & $\begin{array}{c}2013 / 1 \\
1\end{array}$ & 2011 & 2012 & 2013 & $\begin{array}{c}2011- \\
13\end{array}$ & $\begin{array}{c}2011- \\
13\end{array}$ \\
\hline Alior & 8811 & 8410 & 5764 & 7662 & $-17 \%$ & 1442 & 1550 & 741 & 1244 & $-49 \%$ \\
\hline mBank & 8001 & 8060 & 8209 & 8090 & $1 \%$ & 4670 & 4042 & 4059 & 4257 & $-13 \%$ \\
\hline Raiffeisen & 11814 & 21274 & 32360 & 21816 & $87 \%$ & 8624 & 759 & -5172 & 1404 & \\
\hline ING BŚ & 6397 & 5797 & 5885 & 6026 & $-4 \%$ & 2215 & 1569 & 1616 & 1800 & $-27 \%$ \\
\hline BZ WBK & 13269 & 14622 & 18101 & 15331 & $18 \%$ & 4613 & 6129 & 5372 & 5372 & $16 \%$ \\
\hline $\begin{array}{l}\text { Millenniu } \\
\text { m }\end{array}$ & 17064 & 15967 & 12158 & 15063 & $-14 \%$ & 7345 & 7090 & 8017 & 7484 & $9 \%$ \\
\hline BNP & 14959 & 12225 & 11167 & 12784 & $-13 \%$ & $\begin{array}{l}-10 \\
255\end{array}$ & $\begin{array}{l}-11 \\
574\end{array}$ & -6825 & -9551 & $-33 \%$ \\
\hline Getin & 14538 & 6908 & 4709 & 8718 & $-34 \%$ & 10330 & 4356 & 3450 & 6045 & $-67 \%$ \\
\hline Pocztowy & 2083 & 2430 & 2145 & 2220 & $1 \%$ & -151 & 56 & 195 & 34 & \\
\hline CA & 11740 & 10996 & & 11368 & $-3 \%$ & 1373 & 1857 & 1983 & 1738 & $44 \%$ \\
\hline BPH & 17485 & 25053 & 22308 & 21616 & $14 \%$ & 2179 & 5071 & 3370 & 3540 & $55 \%$ \\
\hline
\end{tabular}




\begin{tabular}{|l|c|c|c|c|c|c|c|c|c|c|}
\hline PKO BP & 14166 & 14078 & 12753 & 13665 & $-5 \%$ & 5414 & 5528 & 5160 & 5368 & $-5 \%$ \\
\hline BOŚ & 8742 & 9086 & 7109 & 8312 & $-9 \%$ & -1453 & -1588 & -1899 & -1647 & $31 \%$ \\
\hline Pekao & 13784 & 13449 & 13259 & 13497 & $-2 \%$ & 4597 & 5247 & 5165 & 5003 & $12 \%$ \\
\hline Citi & 21890 & 22099 & 23609 & 22533 & $4 \%$ & 4110 & 6556 & 7011 & 5892 & $71 \%$ \\
\hline BĠ் & 7168 & 7375 & 6809 & 7117 & $-3 \%$ & -1637 & -1031 & -811 & -1160 & $-50 \%$ \\
\hline $\begin{array}{l}\text { Euroban } \\
\text { k }\end{array}$ & 5789 & 4554 & -977 & 3122 & $-58 \%$ & & 1158 & & 1158 & \\
\hline
\end{tabular}

Źródło: opracowanie własne

CLV na zysku z działalności podstawowej utrzymuje się w czasie na dość stabilnym poziomie średnio ok 11,5 tys., przy czym trzeci kwartyl Q3 (14,7 tys) jest ok dwa razy wyższy od kwartyla pierwszego Q1 (7,7tys), który ma najwyższą, bo prawie $30 \%$ tendencję spadkową z 8,2 do 5,8 tys., co świadczy o koncentracji wojny cenowej w tym kwartylu. CLV na wyniku z działalności podstawowej koreluje się powyżej $50 \% \mathrm{z}$ rentownością brutto, operacyjną i sprzedaży, ze wskaźnikiem Altmana (do 81\%), pokryciem odsetkowym, ujemnie natomiast z zadłużeniem (do -85\%), ma jednak ujemny wpływ na pozyskanie.

Rysunek 4. CLV obliczone na zysku z działalności podstawowej

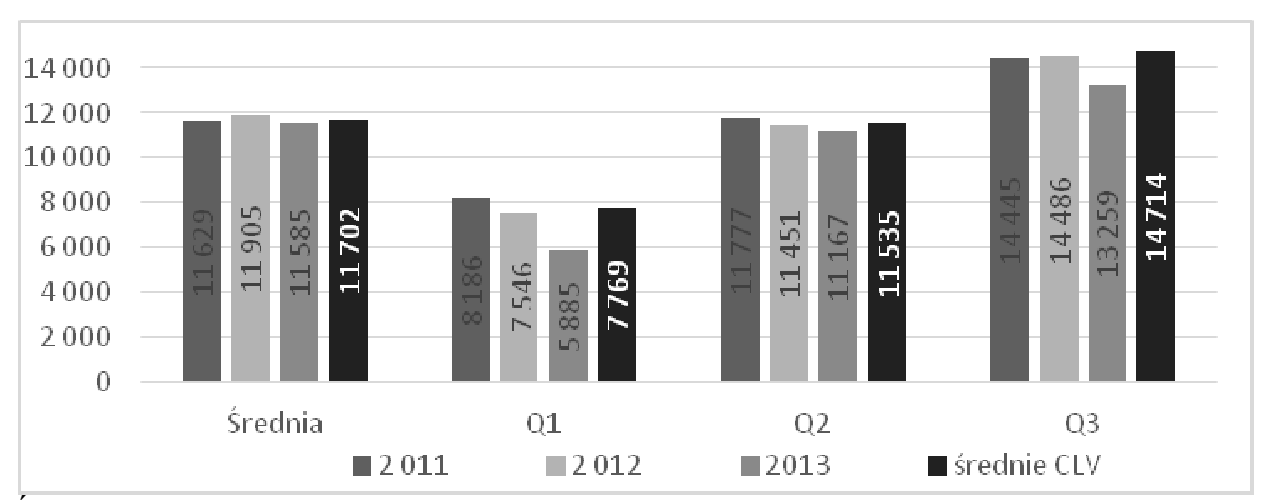

Źródło: opracowanie własne

Średnie CLV na zysku brutto spadło z 2,7 do 2,0 tys. - odzwierciedla to rzeczywistą, po odliczeniu wszystkich kosztów działania wartość życiową klienta banku detalicznego. Banki w kwartylu pierwszym Q1 miały CLV niższe od 1 tysiąca PLN, w kwartylu drugim Q2 1,8 tysiąca, a najbardziej lukratywne banki trzeciego kwartyla Q3 osiągały wyniki zbliżone do 5 tysięcy. CLV oparte na zysku brutto wykazało korelację wyższą niż 50\% z przychodem operacyjnym, z rentownością netto, brutto, operacyjną (ale nie sprzedaży), z ROE, ROA, marżą odsetkową, ze wskaźnikiem Altmana oraz płynnością, pokryciem odsetkowym, ale także $\mathrm{z}$ obciążeniem podatkowym i odsetkowym; ujemną natomiast z przyrostem zysku na akcję, z C/I, udziałem długu w kapitale, cyklem rotacji należności. Podobnie jak wiele wskaźników korelacja z 
przyrostem wartości 2011/13 wykazała tendencje wyrównawcze (odwrotne do statycznych).

Rysunek 5. CLV obliczone na zysku brutto

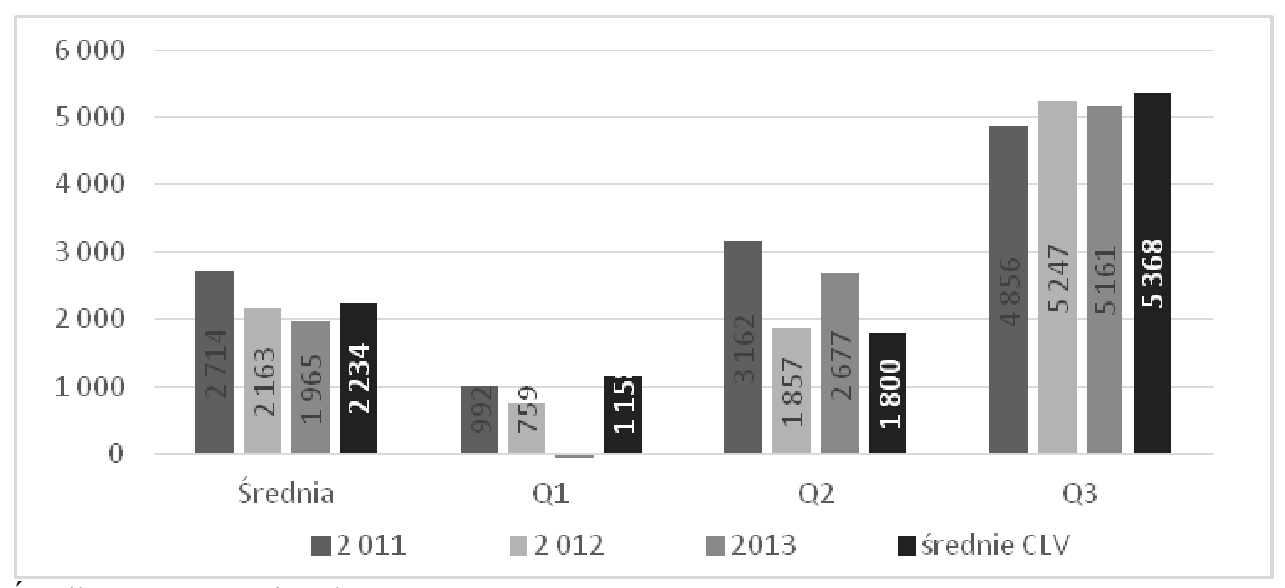

Źródło: opracowanie własne

Warto przyjrzeć się w tym miejscu składowym CLV, które określimy jako zysk oraz mnożnik. Banki mogą inwestować w podnoszenie marży albo wzrost retencji, gdyż klient którego relacja z bankiem się wydłuży może okazać się bardziej zyskowny niż klient wysokomarżowy. W przypadku banków polskich, przy wysokiej retencji oscylującej wokół 95,3\% rocznie, ten wybór dokonuje się często między marżą a mnożnikiem zysku na klienta, który poza retencją uwzględnia też stopę dyskontową i prognozowany wzrost. Rysunek 6 i 7 przedstawiaja, jak największe polskie banki budują wartość klienta - z jednej strony poprzez marżę na klienta oraz z drugiej strony poprzez mnożnik. Ścisła czołówka satysfakcji klienta (Alior, ING oraz mBank), na co warto zwrócić uwagę, znajduje się w ćwiartce potwierdzającej wysoką wartość mnożnika, lecz ich marża na klienta osiąga niskie wartości. Kolejne banki Millennium i WBK sprawnie balansują między satysfakcją a marżą klienta. 
Rysunek 6. Składowe CLV obliczonego na zysku z działalności podstawowej

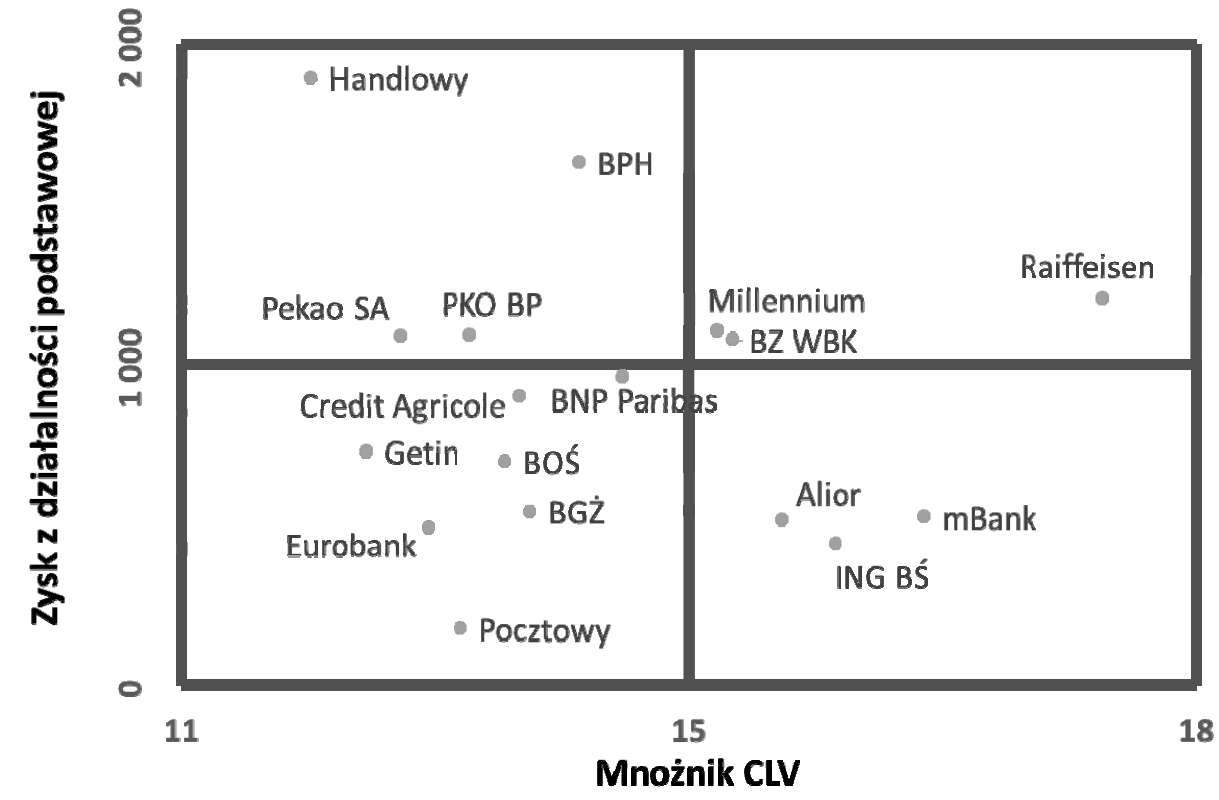

Rysunek 7. Składowe CLV obliczonego na zysku brutto

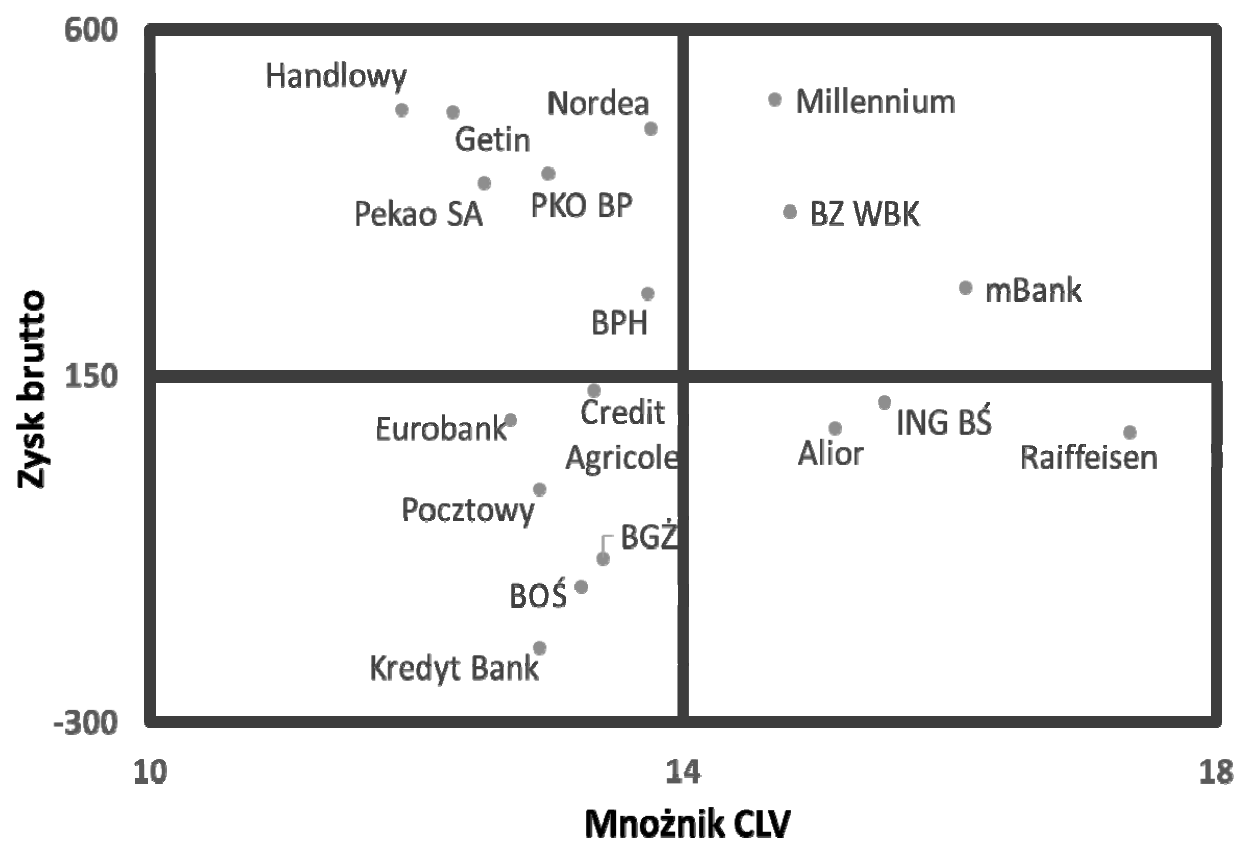


Mnożnik nie wykazuje wielu korelacji ze wskaźnikami finansowymi banków (Tabela 3). Jeśli wziąć pod uwagę same korelacje, bez badania dokładnego układu sił na rynku banków giełdowych, wówczas okaże się, iż najwięcej mnożnik ma korelacji negatywnych ze wskaźnikami związanymi z ryzykiem upadłości (Altman, poziom zadłużenia, udział odpisów aktualizacyjnych, dźwignia oraz płynność bieżąca). Wskaźnik Altmana i poziom zadłużenia są gorsze, niż u rywali, jednak badanie dynamiki wykazuje, iż banki charakteryzujące się wysokim mnożnikiem szybciej je poprawiały.

Tabela 3. Znaczące korelacje mnożnika CLV

\begin{tabular}{|l|l|}
\hline Korelacje mnożnika & Zmiana 2011/13 \\
\hline Zysk na działalności podstawowej & $60,8 \%$ \\
\hline Zysk na działalności podstawowej na klienta & $59,8 \%$ \\
\hline $\begin{array}{l}\text { CLV* liczba klientów (zysk na działalności } \\
\text { podstawowej) }\end{array}$ & $50,0 \%$ \\
\hline Przyrost wartości rynkowej & $36,7 \%$ \\
\hline
\end{tabular}

Źródło: opracowanie własne

Kolejnym wnioskiem jest potwierdzona już teza, iż satysfakcja klienta powinna być badana pod kątem dynamiki a nie wartości statycznych. Jej wpływ jest widoczny zwłaszcza na poziomie przychodu, tu: wyniku na działalności podstawowej. I rzeczywiście zarówno wynik jak i wynik/klienta a także kapitał klienta mierzony na tym poziomie rosną szybciej w firmach o mnożniku na wysokim poziomie. Podobnie MV przyrastała szybciej w bankach o wysokim poziomie mnożnika.

Warto w tym momencie nadmienić, iż NPS wykazuje delikatnie negatywną korelację z zyskiem na działalności podstawowej na klienta. Liderzy NPS (Alior (17\% $\downarrow$ ), mBank i ING) oscylują w okolicach pierwszego kwartyla, natomiast tzw. średniacy (WBK $(+17 \%)$ i Millennium (-13\%)) konkurują NPS przy zachowaniu wyższych marż.

Rysunek 8. Zysk na działalności podstawowej na klienta 2011-2012

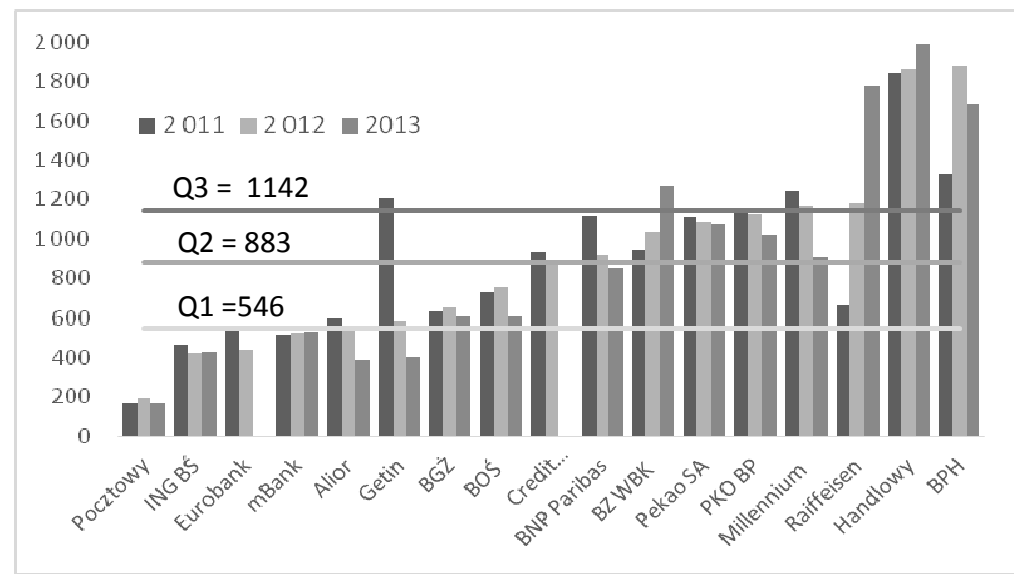

Źródło: opracowanie własne 
Zysk na działalności podstawowej, mimo 2\% wzrostu średniej w Q1 i Q2, wykazuje tendencje spadkowe (odpowiednio o $-19 \%$ i $-9 \%$ ), co sugeruje iż banki planujące agresywny wzrost zaczynają wojny cenowe. Trudno też odnieść się do założeń badawczych, w tym zwłaszcza liczby klientów w bankach objętych badaniem, jednak wydaje się, iż skala utargu na działalności podstawowej jest mocno zróżnicowana, mimo iż banki zasadniczo stosują podobną politykę cenową. Można rozpocząć rozważania na temat roli polityki darmowego RORu w bakach, które są liderami wzrostu. Walka o wzrost sprawia, iż rynek wydaje się podzielony na banki Q3, których wynik jest dwukrotnie wyższy od banków Q1.

Rysunek 9. Zysk na działalności podstawowej na klienta 2011-2013, kwartyle

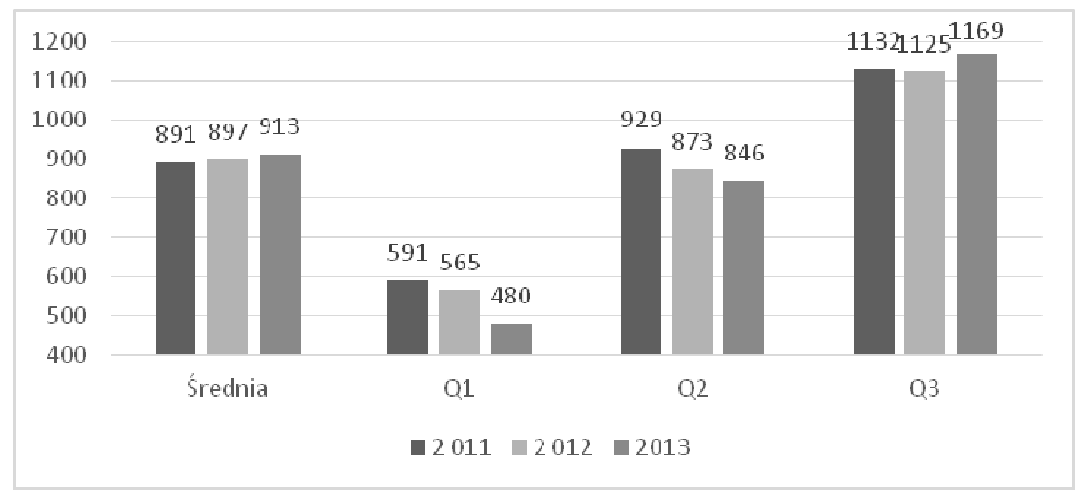

Źródło: opracowanie własne

Teoretycy często wskazuja na konieczność inwestowania w pozyskanie i retencję klientów o wysokim CLV. Wymaga to doskonałej znajomości klientów i wiedzy na temat segmentów, z którymi współpraca układa się najlepiej a następnie podejmowanie prób pozyskania większej liczby klientów z danego segmentu. Nie można tego osiagnąć bez uczenia się klienta, jego zachowań, preferencji, co może wymagać wykorzystania potencjału systemów przechowujących dane o klientach i szeroko rozumianej analityki skoncentrowanej na klientach.

\section{Kapitał klienta detalicznego $\mathrm{w}$ bankach polskich}

CLV poza lepszym zarządzaniem bazą kliencką dostarcza też informacji na temat przewidywanych przepływów pieniężnych od klientów, co jak już wspomniano powinno stanowić prognozę wartości rynkowej firmy. W niniejszym artykule kapitał klienta definiujemy, jak wcześniej wskazano, jako iloczyn wartości życiowej klienta banku oraz liczby klientów (CLV * liczba klientów), co w uproszczeniu daje zysk pomnożony przez mnożnik (z licznika znika bowiem liczba klientów), który jak wskazano w rozdziale dotyczącym CLV mieści się $\mathrm{w}$ przedziale 11-18 dla badanych banków. Wartość ta powinna stanowić prognozowaną wartość rynkową banku. W niniejszym rozdziale zbadamy wpływ detalicznego segmentu operacyjnego i korelacji kapitału klienta detalicznego z wartością rynkową banku. 
Suma kapitału klienta liczonego w oparciu o zysk z działalności podstawowej w segmencie detalicznym banków objętych badaniem kształtowała się na poziomie ok 350 mld PLN, 4 największe banki miały 67\% udziału w sumie 17 banków objętych badaniem. Średnia na stabilnym poziomie ok $21 \mathrm{mld}$, podobnie jak Q3. Q1 i Q3 miały tendencję spadkową (-16\% i -7\%) a Q3 wzrósł o 14\% w dużej mierze dzięki wynikowi BZ WBK. Pierwszym jednak wnioskiem, który zwraca uwagę jest dramatyczna przewaga dwóch największych banków i trudności konkurowania na rynku przez nich zdominowanym. Banki mniejsze osiagają niskie zyski z działalności podstawowej i powolnie rosną przy niewielkiej marży. PKO BP i Pekao SA mogą, wobec charakterystycznej dla rynku bankowego wysokiej retencji, którą badacze TNS Polska określili mianem bezwładu i zastoju, osiąać wysokie marże mimo posiadania bardzo dużej bazy klientów (Rysunek 10).

Rysunek 10. Średni kapitał klienta banków detalicznych za lata 2011-2013 (na zysku z działalności podstawowej)

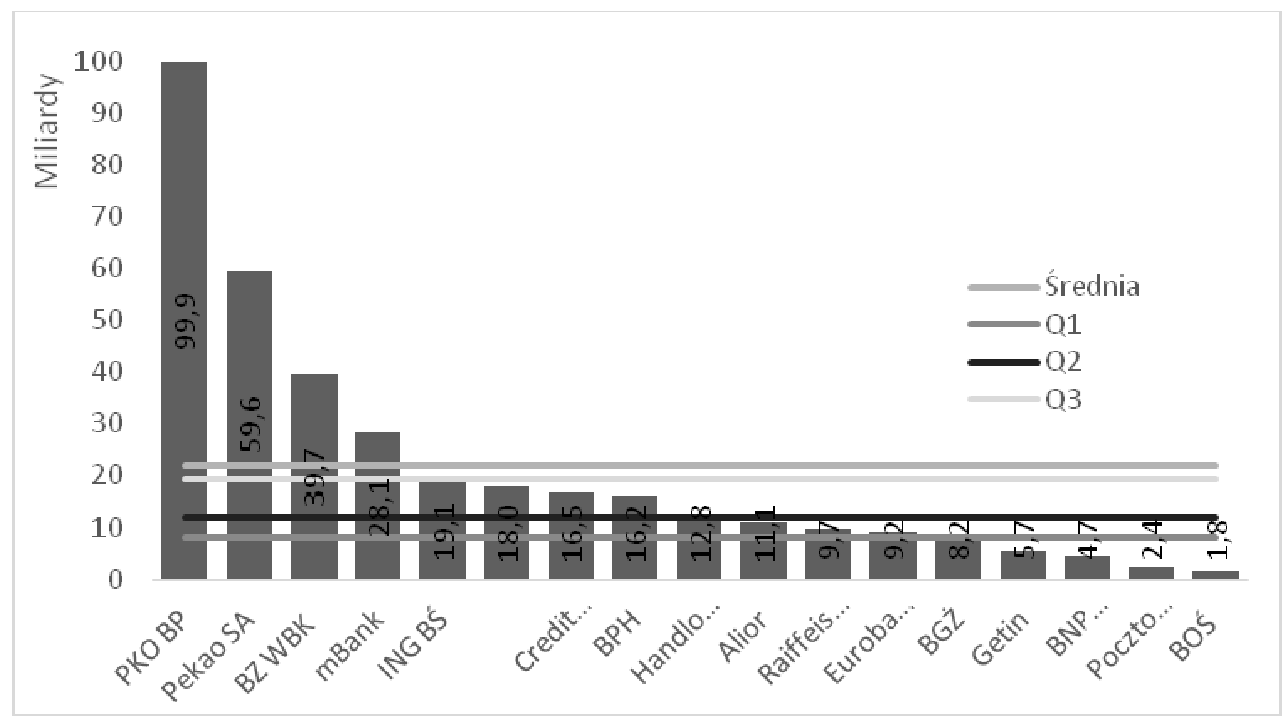

Źródło: opracowanie własne

Suma kapitału klienta wyliczonego na zysku brutto 15 banków objętych badaniem utrzymywała się na stałym poziomie i wynosiła około $120 \mathrm{mld}$, z czego 4 największe banki przejęły $72 \%$ wartości. Banki objęte badaniem miały kapitał klienta na średnim poziomie ok 9 mld, poniżej Q3. Tendencja spadkowa wystąpiła w Q1 i Q2 (odp. $8 \%$ i $40 \%$ ) oraz wzrostowa w Q3 (+26\%) na skutek poprawy wyniku w BZ WBK. Wartości wyodrębnionych kwartyli podlegały większym wahaniom niż dla kapitału klienta na zysku z działalności podstawowej. BOŚ, BGŻ i BNP nie zostały objęte badaniem, gdyż wykazały stratę brutto na detalu, Raiffeisen wszedł na stratę, a Pocztowy z niej wyszedł. 
Rysunek 11. Średni kapitał klienta banków detalicznych za lata 2011-2013 (na zysku brutto)

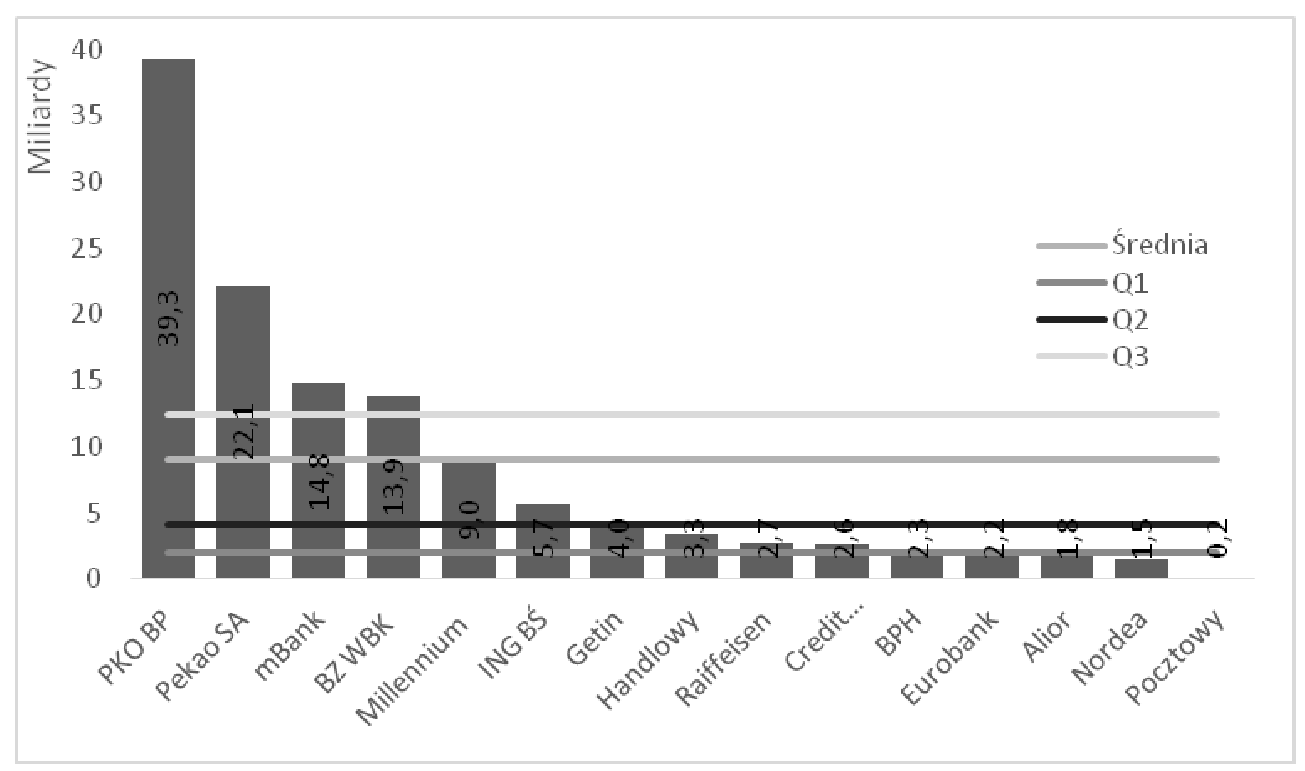

Źródło: opracowanie własne

Spróbujmy więc przejść do kluczowego badania - szukania korelacji między kapitałem klienta a wartością rynkową banków dla segmentu detalicznego. Uzyskane korelacje są wysokie zarówno dla kapitału liczonego na zysku z działalności podstawowej jak i zysku brutto. Zaskakująco wysoka przewyższająca $90 \%$ okazała się korelacja między wyceną rynkową banków a ich kapitałem klienta (liczonym na zysku z działalności podstawowej) przy R2 bliskim 90\%. Relacja MV/CLV rośnie od 0,5 do 0,8; regresja od 0,43 do 0,57 w latach 2011-2013. Świadczy to o rosnącej wartości giełdowej firmy w stosunku do kapitału klienta.

Tabela 4. Korelacje kapitału klienta detalicznego (CLV na zysku z działalności podstawowej) $\mathrm{z}$ wartością rynkową banków

\begin{tabular}{|l|l|l|l|}
\hline & $\mathbf{2 0 1 1}$ & $\mathbf{2 0 1 2}$ & $\mathbf{2 0 1 3}$ \\
\hline KORELACJA & $93 \%$ & $93 \%$ & $95 \%$ \\
\hline R2 & $87 \%$ & $87 \%$ & $90 \%$ \\
\hline
\end{tabular}

Źródło: opracowanie własne

Relacja wartości rynkowej do wartości bazy klientów detalicznych liczonej na zysku z działalności podstawowej rośnie w latach 2011-13 z 0,5 do 0,8. Celem ukazania rzeczywistego wpływu detalu na wartość firmy przyjęłam, iż MV można dla przybliżenia zważyć udziałem wyniku z działalności podstawowej w wyniku całego banku na działalności podstawowej - wówczas wartość kształtuje się MV/CLV = 0,3. Rysunek 12 obrazuje relację dla roku 2011, tak aby uwidocznić pozycję poszczególnych 
banków. Widoczny wydaje się dobry wynik Pekao SA. PKO BP natomiast mimo dużej przewagi nad innymi bankami wydaje się niedoceniony przez inwestorów.

Rysunek 12. MV a Kapitał klienta (zysk dz.podst) w bankach polskich 2011

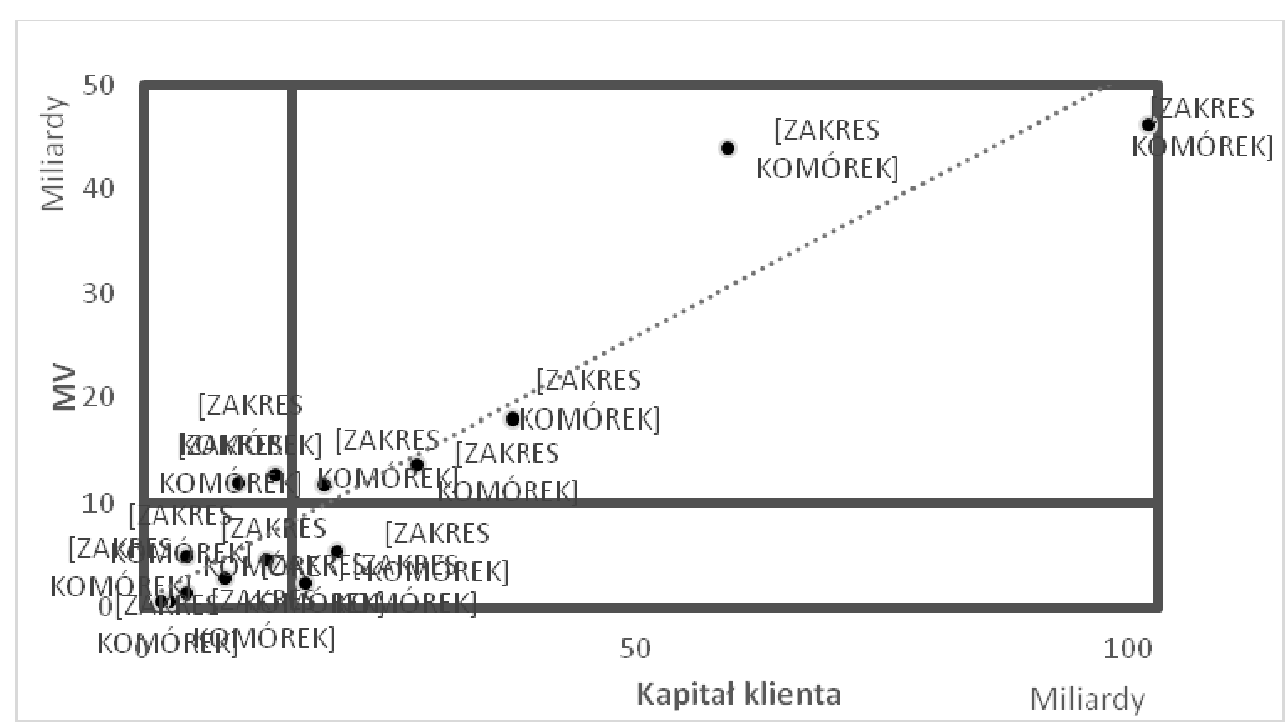

Źródło: opracowanie własne

Kolejnym wnioskiem jest rosnące nachylenie krzywej regresji na wykresie obrazującym, jak zależność miedzy kapitałem klienta a wartością rynkową zmienia się w czasie $w$ latach 2011-2013. Nachylenie wzrasta z 0,43 do 0,58 w 2013. Prowadzić to może do konkluzji, iż podniesienie kapitału klienta o jednostkę coraz bardziej pomnaża przyrost wartości rynkowej. Z 0,93 do 0,95 poprawia się współczynnik korelacji. Powolnie, bo jedynie z 0,87 do 0,90 , rośnie także współczynnik R2 obrazujący stopień dopasowania danych do modelu korelacji liniowej. 
Rysunek 13. MV a Kapitał klienta (zysk dz.podst) w bankach polskich -rosnące nachylenie $\mathrm{k}$. regresji

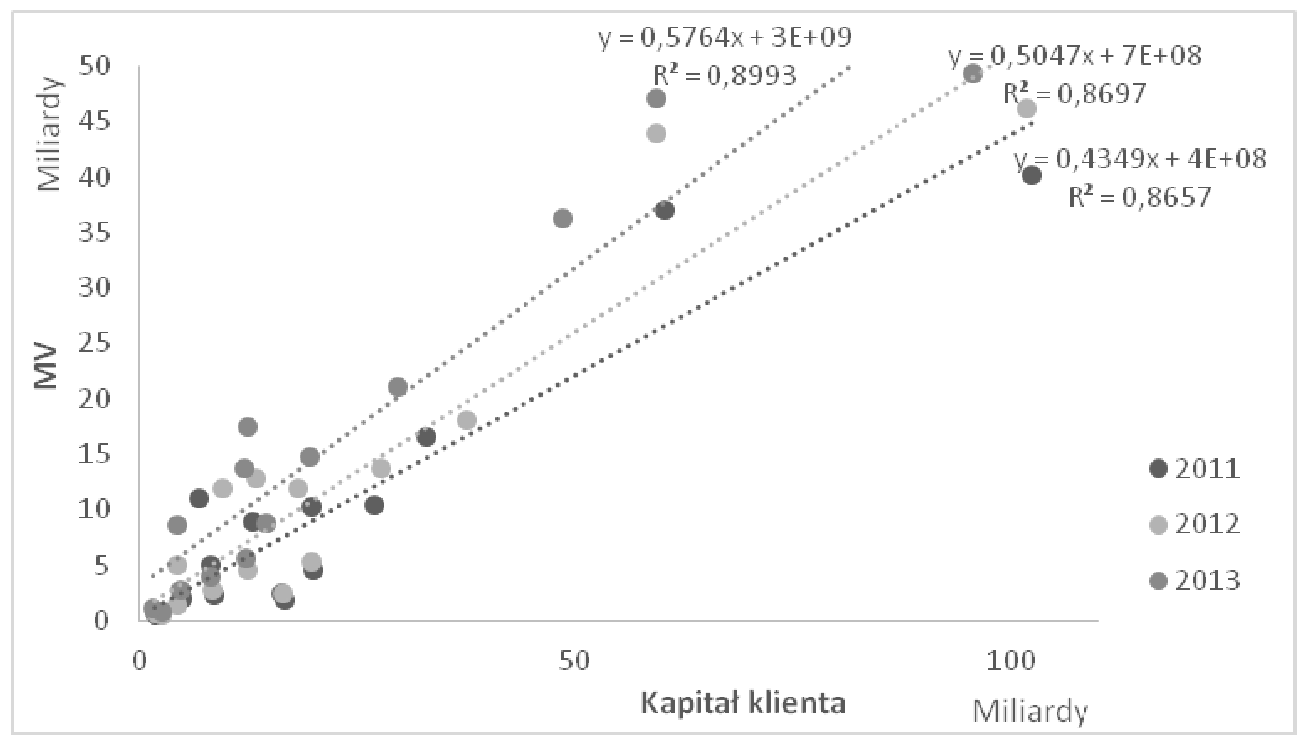

Źródło: opracowanie własne

Dane dla CLV liczonego na zysku brutto w detalu, mimo uwzględnienia wszystkich kosztów i odpisów z tytułu utraty wartości w bankach nie wykazują różnicy. Korelacja jest bardzo wysoka - utrzymuje się na wyskokiem poziomie 0,9 i rośnie w badanym okresie o 2 punkty procentowe, współczynnik R2 o 4 punkty procentowe z 0,81 do 0,85 . Wskazuje to na wzrost korelacji liniowej w modelu w badanym okresie.

Tabela 5. CLV*cust base (na zysku brutto) versus MV

\begin{tabular}{|l|l|l|l|}
\hline & $\mathbf{2 0 1 1}$ & $\mathbf{2 0 1 2}$ & $\mathbf{2 0 1 3}$ \\
\hline Korelacja & 0,90 & 0,91 & 0,92 \\
\hline R2 & 0,81 & 0,83 & 0,85 \\
\hline
\end{tabular}

Źródło: opracowanie własne

W kategoriach CLV na zysku brutto całkowita wartość rynkowa banków MV rośnie od 1,5 do 2,2x wartości bazy klientów detalicznych wyrażonej w wartości bieżących i przyszłych przepływów pieniężnych od tych klientów. Mamy więc do czynienia z corocznym 20\% wzrostem relacji MV do wartości bazy klientów detalicznych. Proporcje nie ulegają nadmiernej zmianie. Spośród liderów NPS mBank i Millennium wydają się niedowartościowane. 
Rysunek 14. Kapitał klienta (z.brutto) a MV banków detalicznych 2011

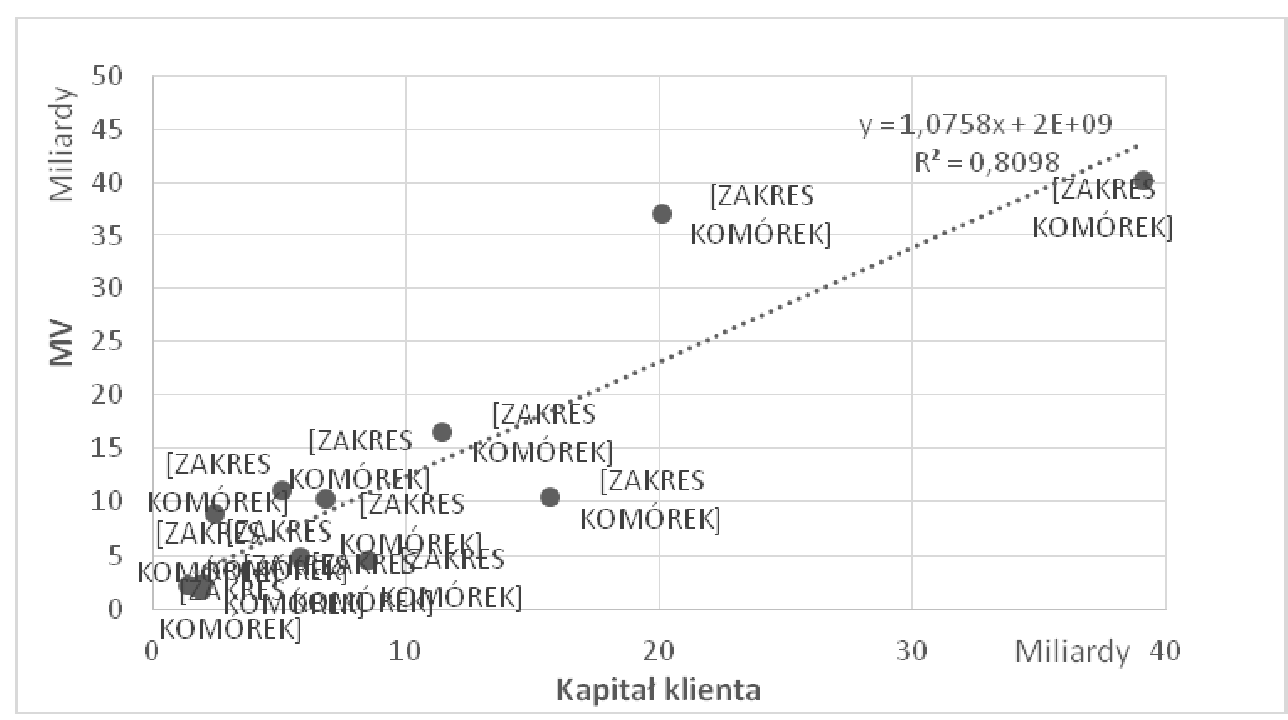

Źródło: opracowanie własne

Kolejnym powracającym wnioskiem jest wzrost zarówno nachylenia jak i wysokości krzywej regresji, co oznacza stopniowy wzrost wartości rynkowej w relacji do kapitału klienta, ale też większą moc kapitału klienta którego wzrost o jednostkę zwiększa prognozowaną wartość rynkową o 1 w 2011 i w 2013 już 1,4.

Rysunek 15. MV vs kapitał klientów detalicznych (zysk brutto) banków polskich 20112013

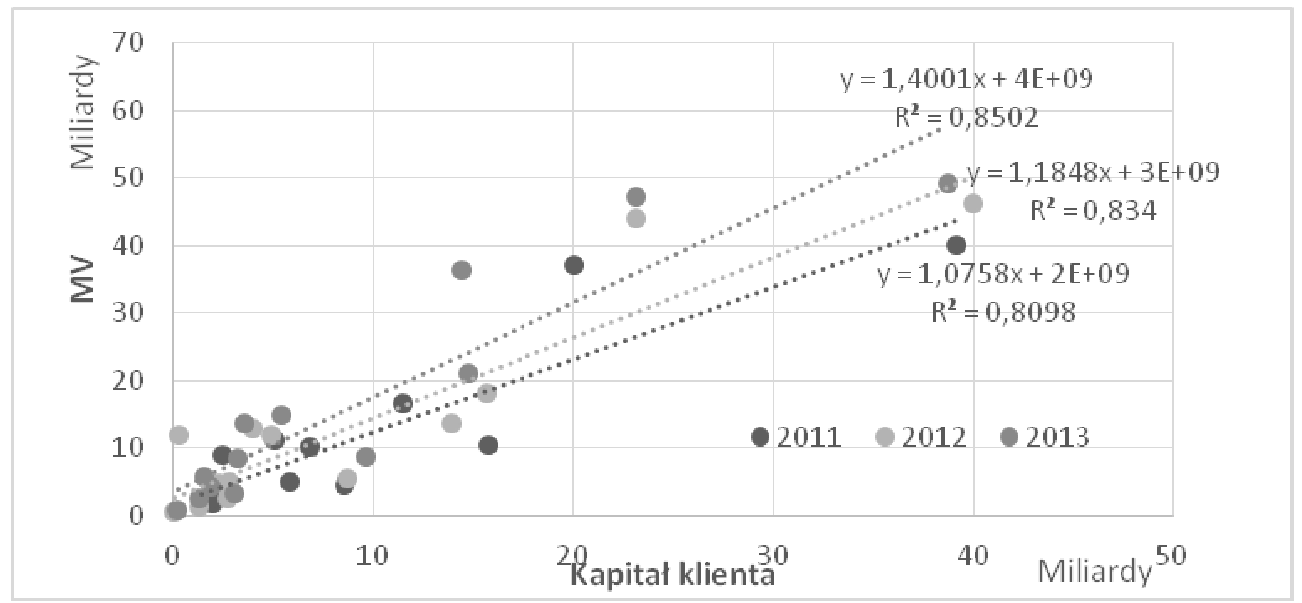

Źródło: opracowanie własne 
Dla przybliżenia, jeśli pomniejszymy wartość giełdową MV banków (przynoszących zyski na detalu) ważąc ją udziałem zysku z działalności podstawowej na detalu w całkowitym zysku z działalności podstawowej banku okaże się że w latach 2011 i 2012 relacja MV do wartości bazy klientów była bliska 1, a w 2013 wzrosła do 1,4 .

Rysunek 16. MV (detaliczne)/CLV*liczba klientów (CLV na zysku brutto)

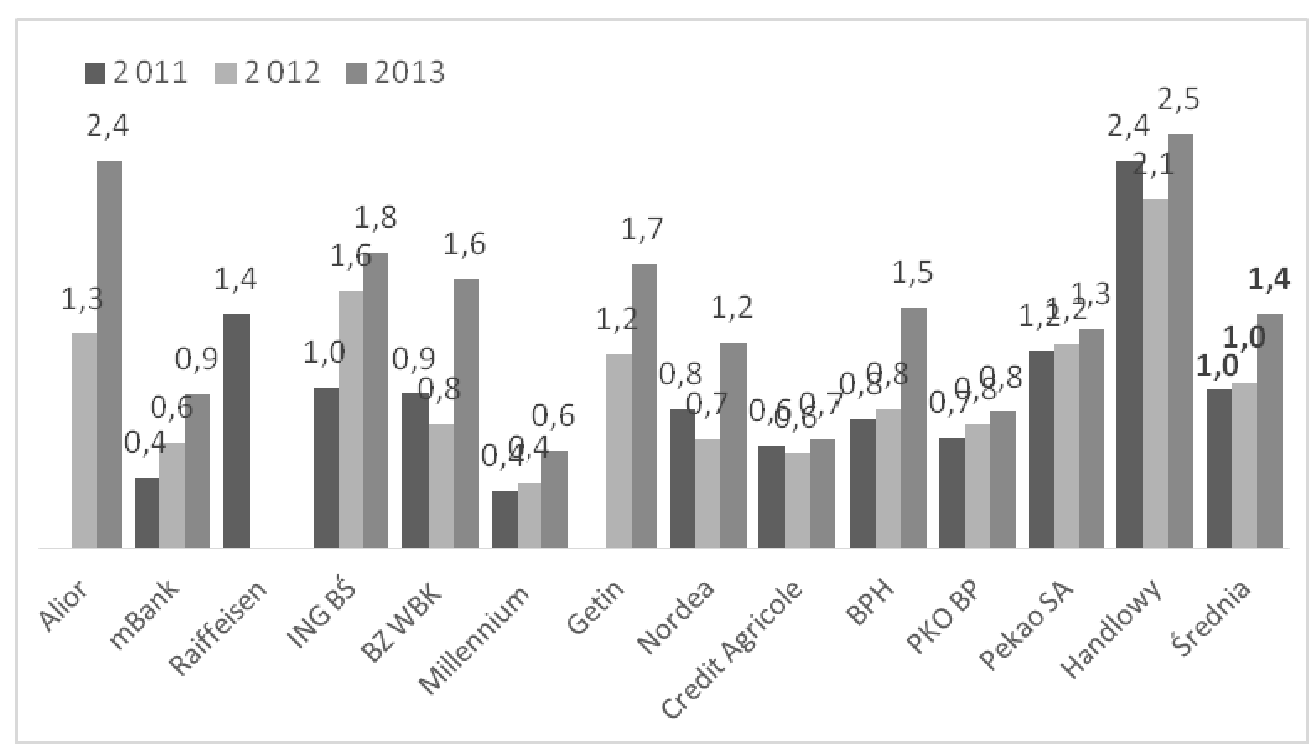

Źródło: opracowanie własne

\section{Podsumowanie}

Niniejsze badanie miało na celu wskazanie ogólnych wniosków wynikających z badań porównawczych wartości życiowej klienta (CLV), najpierw na poziomie wartości życiowych wypracowywanych przez poszczególne banki a następnie roli budowy wartości rynkowej $\mathrm{w}$ oparciu o kapitał klienta. Wskazuje to na dwa kluczowe zastosowania CLV: na poziomie jednostkowym, a następnie segmentów CLV powinno bankom służyć w lepszym i bardziej efektywnym zarządzaniu bazą klientów, które powinno służyć optymalizacji ich wartości życiowej oraz z drugiej strony na poziomie zagregowanym do wyznaczania możliwych wycen firmy, co jest możliwe w wypadku tego sektora ze względu na bardzo wysoką korelację między kapitałem klienta a wyceną banku. Istotne korelacje wykazywane przez oba wskaźniki sugerują konieczność pogłębienia badań w tym zakresie, zwłaszcza wpływie CLV na wyniki finansowe banku, a także kapitału klienta w bankowości korporacyjnej i jej wpływu na wartość rynkową. 


\section{Literatura}

G. S. Day, Ch. Moorman, Strategy from the Outside In. Profiting from the Customer Value, McGraw Hill, 2010.

B. Dobiegała-Korona, Kierunki i wyzwania rozwoju zarządzania wartością klientów, w: red. B. Dobiegała Korona, Budowa wartości klienta - teoria i praktyka, Difin, Warszawa, 2015.

B. Dobiegała - Korona, Klient kapitałem przedsiębiorstwa, w: red. B. Dobiegała - Korona, A. Herman, Współczesne źródła wartości przedsiębiorstw, Difin, Warszawa, 2006.

P. Fader, Customer Centricity, Focus on the Right Customers for Strategic Advantage, Wharton Executive Essentials, Philadelphia, 2012.

S. Gupta, D.R. Lehman, J.A. Stuart, Valuing Customers, Journal of Marketing Research, XLI, 2004.

J. Villanueva, D.M. Hanssens, Customer Equity: Measurement, Management and Research Opportunities, Foundations and Trends in Marketing, Vol. 1, No. 1 (2007).

\section{Abstract}

The following article focuses on researching the dependencies between customer lifetime value CLV and the market valuations MV on the Polish banking sector. Many authors (P. Seybold, S. Gupta, D. Lehmann, R. Boulton, B. Liebert, S. Samek, R. Heiebeler, T. Kelly, Ch. Ketteman, P. Doyle) were claiming that there is a positive dependency between the value of future cash flows from the customer base of the company and its forecasted market valuation by the investors. Article's main goal is to explain CLV methodology and to investigate correlations of this index with the financial results of Polish stock exchange banks. It also focuses on the methodologies and difficulties of appropriate estimation of the CLV. In this case two methods will be taken into account - first traditional measured on the Other Income and second hypothetically more accurate measured on Gross Income in the retail operating segment. Next the author will try characterize the customer equity calculated both for the Other Income CLV and the Gross Profit CLV on the Polish retail banking market, for the stock exchange banks. There is a lot of research confirming a positive correlation between the estimated value of future cash flows from the base of customers and the market value of the company. Finally a hypothesis of a high correlation between lifetime value of the customer base of the bank and its market value will be verified.

Key words: customer lifetime value, market value of a firm, retail banking

Informacja o autorze:

mgr Aleksandra Snarska

Zakład Marketingu Wartości

Szkoła Główna Handlowa

e-mail: aleksandra.snarska@gmail.com 